УДК 81’276.16:[791:821.111-312.9]Керрол

DOI https://doi.org/10.26661/2414-1135-2021-84-1

\title{
ПСИХОЛІНГВІСТИЧНИЙ ОБРАЗ АЛІСИ У ФІЛЬМI Т. БЕРТОНА ALICE IN WONDERLAND
}

\author{
Бережна М. В. \\ кандидатка філологічних наук, \\ докторантка кафедри теорї та практики перекладу з англійської мови \\ Запорізький національний університет \\ вул. Жуковського, 66, Запоріжжя, Україна \\ orcid.org/0000-0002-3345-256X \\ margaret.berezhna@gmail.com
}

Ключові слова: мовленнєвий
портрет, архетип
«Амазонка», кіноархетип,
персонажне мовлення,
кінодіалог.
У статті розглядаємо мовленнєвий портрет персонажа за психологічним архетипом «Амазонка» у фільмі Т. Бертона Alice in Wonderland (2010). За основу взято класифікацію архетипів В. Шмідт (2007). У роботі проаналізовано вчинки та мовлення Аліси Кігнслі, визначено риси характеру, які дозволяють віднести персонаж до психотипу «Амазонка», а також встановлено характерні особливості мовлення, які слугують безпосереднім проявом психотипу.

Риси, які дозволяють віднести Бертонівську Алісу до архетипу «Амазонка»: 1) Аліса у фільмі феміністка і відстоює своє право на рівність $з$ чоловіками наперекір суспільному осуду; 2) вона прийде на допомогу іншим, незважаючи на смертельну небезпеку для себе самої; 3) вона любить подорожувати та досліджувати нові землі; 4) вона не боїться провести ніч на самоті просто неба; 5) найбільший ії страх - не бути здатною подбати про себе (фізично чи фінансово); 6) вона завжди прийме виклик від чоловіка і не відступиться, поки не переможе; 7) вона цінує жіночу дружбу, але має більше друзів серед чоловіків; 8) вона керується інтуїцією частіше, ніж логікою; 9) вона настільки сконцентрована на досягненні мети, що може сприйматися як байдужа і відчужена.

Характерними для мовлення Аліси у фільмі Т. Бертона є такі елементи:

1) окличні речення у поєднанні 3 апелятивами для привернення уваги адресата чи для формування директивів, що свідчить про силу волі, здатність приймати рішення і брати на себе відповідальність; 2) декларативи у формі окличних речень для емфатизації сенсу, а також під час висловлювання таких емоцій, як подив, гнів, роздратування, розпач, коли на ії шляху до мети з'являються перешкоди; 3) прямі квеситиви, які вимагають відповіді від співрозмовника; 4) прямі та непрямі директиви як засіб реалізації лідерської функції персонажа; 5) складні речення 3 причинно-наслідковим зв'язком для демонстрації логіки мислення, заснованої переважно на інтуїції.

У мовленні Аліси майже відсутні оцінні лексеми, відповідно, характерною $\epsilon$ стриманість у висловлюваннях і оцінках; майже однакова частотність займенників першої особи однини та другої особи однини й множини демонструє, з одного боку, самодостатність, незалежність персонажа, вміння покладатися передусім на себе, а з іншого - піклування про інших, альтруїзм та концентрацію на потребах співрозмовника. 


\title{
PSYCHOLINGUISTIC IMAGE OF ALICE IN T. BERTON'S FILM ALICE IN WONDERLAND
}

\author{
Berezhna M. V. \\ Candidate of Philological Sciences, \\ Doctoral Student at the Department of English Translation Theory and Practice \\ Zaporizhzhia National University \\ Zhukovskoho str., 66, Zaporizhzhia, Ukraine \\ orcid.org/0000-0002-3345-256X \\ margaret.berezhna@gmail.com
}

Key words: speech portrait, Amazon archetype, film archetype, character's speech, film dialogue.
In the article, I consider the speech patterns of the character belonging to the archetype "Amazon" in T. Burton's film Alice in Wonderland (2010). The classification of archetypes by W. Schmidt (2007) is taken as the basis of the research. In the article, I analyze the actions and speech of Alice Kinsley, identify those character traits that allow to attribute Alice to the psychotype "Amazon", and classify the characteristic features of speech serving as the direct manifestation of the psychotype.

Traits allowing to attribute Burton's Alice to the "Amazon" archetype are the following. 1) Alice in the film is a feminist defending her right to equality with men despite public condemnation; 2) she comes to the aid of others despite the mortal danger to herself; 3) she likes to travel and explore new lands; 4) she is not afraid to spend the night alone in the open; 5) her biggest fear is not being able to take care of herself (physically or financially); 6) she always accepts a challenge from a man and will not back down until she wins; 7) she values female friendship, but has more friends among men; 8) she is guided by intuition more often than by logic; 9) she is so focused on achieving the goal that she can be perceived as indifferent and detached.

Alice's speech in T. Burton's film is characterized by the following elements: 1) exclamatory sentences in combination with appeals to attract the attention of the addressee or to form directives that indicate the strength of will, the ability to make decisions and take responsibility; 2) declaratives in the form of exclamatory sentences to emphasize sense, and to express surprise, anger, irritation, despair, when there appear obstacles on her way to the goal; 3) direct requests demanding an answer from the interlocutor; 4) direct and indirect directives as a means to demonstrate leadership abilities of the character; 5) complex sentences with a cause-and-effect relationship to demonstrate the logic of thinking, based mainly on intuition.

In Alice's speech there is almost no evaluative lexis, respectively, she is perceived as reserved in speech and evaluations. Almost equal frequency in the usage of pronouns of the first person singular and second person singular and plural demonstrates on the one hand self-sufficiency, independence of the character, the ability to rely primarily on herself, and on the other hand it indicates the concern for others, altruism and focus on the needs of the interlocutor.
Постановка проблеми. Мистецтво кіно посідає провідне місце у системі сучасної культури. Воно є дієвим засобом впливу на масову свідомість, а моделі, за якими побудовані діалоги у фільмах для широкого загалу, є загальнозрозумілими та для більшості реципієнтів, незалежно від країни, культури, мови, віку та інших соціальних характеристик, прийнятними в екранних ситу- аціях спілкування. Протягом XX-XXI століть екран став медіумом, посередником між людиною та світом, що інтенсивно впливає на масову свідомість, надає еталонні моделі поведінки, формує ціннісні критерії, породжує «героїв нашого часу» тощо. Слід визнати, що дієвість екранного впливу має цілком об'єктивні підстави, адже культура взагалі та екранна культура зокрема $є$ сферою 
функціонування архетипів, архетипових мотивів та міфологічних образів. Нині, на тлі експансії панівного типу культури, а саме культури екранної, закономірно помічається активізація «архетипової свідомості» та символічного мислення $[1$, c. 75$]$.

Кінообрази використовують енергію міфу, експлуатують архетип, створюють сучасну міфологію, що містить виразний і прагматичний образотворчий потенціал. Кінематограф маніпулює міфологічними зразками, впливаючи і на свідомість, і на підсвідомість глядача, тим самим являючись механізмом, що сприяє самоідентифікації індивіда [2, с. 230].

Діалог між персонажами часто $є$ рушійною силою, яка просуває сюжетні лінії. Персонажі визначають наратив, демонструючи емпатію або конфлікт у межах історії. Правдоподібні персонажі розкриваються перед аудиторією через поєднання їх діалогів та дій в описуваному світі [3, с. 45]. Мовлення персонажів у художньому творі, відображаючи чинні норми та правила спілкування, створює правдиву картину світу та образи самих персонажів. Однак, на відміну від реального повсякденного спілкування, мова персонажів має свої особливості та не $\epsilon$ точним аналогом розмовного мовлення, а його стилізацією [4, c. 196$]$.

Психолінгвістика, як наука, що вивчає «устрій i функціонування мовленнєвих механізмів людини» [5, с. 106], включаючи експериментальне дослідження психологічної діяльності суб' єкта із засвоєння та використання системи мови [6, с. 147], є тою наукою, яка дає можливість поєднати у дослідженні архетип персонажа та особливості його мовлення.

М. Вокер та інші зазначають необхідність «...методу або теорії, яка систематично і повно визначає: 1) найбільш важливу індивідуальну та стилістичну різницю у поведінці; 2) те, як ця різниця впливає на лінгвістичні складники діалогу; 3) прогнозований вплив на сприйняття інформації слухачем» [7]. На думку дослідників, у результаті таку теорію можна використовувати, серед іншого, для створення автоматичного агрегатора персонажного мовлення.

У наявних роботах досліджувалися параметри та моделі мовлення персонажів на основі теорії ввічливості Браун-Левінсона, моделі «Великої п'ятірки», теорій архетипів персонажів, а також методами корпусної лінгвістики. В той час як одні дослідники вважають, що за допомогою методів корпусної лінгвістики можна отримати більш детальну модель мовлення окремого персонажа [7], інші зазначають, що теорія ввічливості Браун-Левінсона та модель «Великої п'ятірки» надають перелік важливих параметрів та моделей персонажного мовлення, а теорія архетипів пропонує цілу систему таких типових персонажів, як «Герой», «Тінь», «Годувальниця», які виконують шаблонні ролі, мають типову особистість і можуть повторно використовуватися у різних наративах. Так, Дж. Роув та інші [3] пропонують евристичну модель поведінки персонажів на основі таксономії з сорока п'яти головних архетипів В. Шмідт [8] і демонструють, як теорію архетипів можна поєднати із побудовою діалогів персонажів в інтерактивних рольових комп'ютерних іграх [9].

На разі робіт, які пропонують використання теорії архетипів В. Шмідт для дослідження і систематизації психолінгвістичних образів персонажів у англомовному кінодискурсі масової культури, немає. Зазначене зумовлює актуальність і новизну пропонованого дослідження.

Мета і завдання роботи - визначити складники психолінгвістичного образу персонажа за архетипом «Амазонка» в англомовному фільмі жанру фентезі для широкого глядацького загалу.

Об'єкт роботи: 193 репліки Аліси Кінгслі, вилучених методом наскрізної вибірки з фільму жанру фентезі Т. Бертона Alice in Wonderland (2010). Предмет: лексико-семантичні, синтаксичні, стилістичні засоби формування психолінгвістичного образу персонажа за архетипом «Амазонка» у сучасних англомовних фільмах для широкої глядацької аудиторії.

Виклад основного матеріалу. Робота є частиною комплексного дослідження цілісної системи психолінгвістичних кіноархетипів найбільш касових фільмів XXI сторіччя.

За класифікацією В. Шмідт відносимо Алісу до архетипу «Амазонка» [8, с. 48], для якої визначальними рисами $€$ такі:

1) Аліса у досліджуваному фільмі Т. Бертона феміністка, яка буде відстоювати своє право на рівність 3 чоловіками навіть попри суспільний осуд. Так, за сюжетом, в реальному світі вона має вийти заміж за молодшого лорда Ескота - пихатого, самозакоханого, розпещеного багатія, який вважає Алісу дивакуватою особою. Старший лорд Ескот був партнером Чарльза Кінгслі, покійного батька Аліси. Цей шлюб є прийнятним і навіть бажаним в очах як родини Кінгслі, так і суспільства загалом, але у самої Аліси не викликає захоплення: ALICE: Well, everyone expects me to... and you're a Lord... my face won't last... and I don't want to end up like... but this is happening so quickly... I think... I think I... I... need a moment [10, 0:11:26].

Подальші пригоди у Дивокраї загартовують характер Аліси, дозволяють у перспективі побачити життя і свій шлях у ньому, подолати страх перед невизначеністю і неоднозначністю положення у суспільстві жінки, яка йде проти усталених традицій і бажає сама визначати свою долю. 
Наприкінці фільму Аліса звертається до старшого лорда Ескота не як до голови сімейства і потенційного свекра, а як до рівного партнера по бізнесу (тактика конфронтації): LORD ASCOT: You've left me out. ALICE: No I haven't, sir. You and I have business to discuss [10, 1:38:14].

2) Вона прийде на допомогу іншим, незважаючи на смертельну небезпеку для себе самої. Вона знаходить свою ідентичність, рятуючи чиєсь життя [8, с. 50]. За сюжетом, Капелюшник, рятуючи Алісу, потрапляє у полон до Червоної Королеви, де його чекає ув'язнення, тортури та страта. Аліса відчуває свою відповідальність за його долю: ALICE: We're going to rescue him. THE BLOODHOUND: That is not foretold. ALICE: I don't care. He wouldn't be there if it weren't for me [10, 0:43:21].

3) Вона любить подорожувати та досліджувати нові землі. Потрапивши до Дивокраю, вона не лякається, не впадає у відчай, а сміливо рухається вперед, коментуючи навколишне так: ALICE: Curiouser and curiouser [10, 0:18:45].

4) Вона не боїться провести ніч на самоті просто неба, що підтверджує сцена ночівлі у полі, коли єдиним захистом для зменшеної Аліси слугує циліндр Капелюшника.

5) Найбільший іiі страх - не бути здатною подбати про себе (фізично чи фінансово). Тут можна навести аргумент сестри на користь заміжжя з лордом Ескотом: MARGARET: And you don't want to be a burden on mother, do you? ALICE: No [10, 0:07:58].

Ця тема знаходить продовження у розмові 3 матір'ю: ALICE: Don't worry, Mother. I'll find something useful to do with my life [10, 1:38:00].

6) Вона завжди прийме виклик від чоловіка і не відступиться, поки не переможе. За сюжетом Капелюшник звинувачує Алісу у втраті колишньої дитячої мужності, відваги: MAD HATTER: You're not the same as you were before. You were much more... much more muchier... you've lost your muchness [10, 0:38:12].

Прийнявши виклик, Аліса рушає назустріч небезпечним пригодам. Спочатку ій потрібно подолати водяний рів навколо замку Червоної Королеви, в якому плавають відсічені голови колишніх бранців жорстокої правительки: ALICE: Lost my muchness have I? [10, 0:45:02].

Далі вона має здобути Зрублавмеч, подолавши свій страх перед Бузогризом: ALICE: How's this for "muchness"? [10, 1:04:25].

7) Вона цінує жіночу дружбу, але має більше друзів серед чоловіків. Серед жіночих персонажів на боці Аліси виступають Біла Королева та Соня, серед чоловічих - Білий Кролик, Капелюшник, брати Круть-верть і Верть-круть, Чеширський Кіт, Абсолем, Баярд, Березневий Заєць.
8) Вона керується інтуїцією частіше, ніж логікою. За сюжетом, побачивши білого кролика у камзолі, Аліса біжить за ним і провалюється у кролячу нору. Потрапивши до Дивокраю, вона беззастережно випиває зменшувальний трунок та їсть збільшувальний пиріг, приймає спонтанне рішення повернути Бузогризу втрачене у сутичці око і дозволяє йому облизати рану, яку він сам же ій і наніс.

9) Вона настільки сконцентрована на досягненні мети, що може сприйматися як байдужа i відчужена. Наприклад, дізнавшись, що дружину i цуценят пса Баярда тримає у заручниках Червона Королева, Аліса не виказує до нього ні співчуття, ні жалю. Коли Білий Кролик від страху втрачає свідомість, Аліса знову ніяк не реагує і не зупиняється, щоб йому допомогти.

Отримані результати свідчать, що для мовленнєвого портрета Аліси характерні:

1) окличні речення у поєднанні з апелятивами для привернення уваги адресата чи для формування директивів, що свідчить про силу волі, здатність приймати рішення і брати на себе відповідальність: ALICE: Bayard! To Marmoreal! [10, 1:06:20].

Цікавим $€$ набір та частотність вживання апелятивів, що вважаємо непрямим засобом ідентифікації персонажів, взаємодія з якими є ключовою для розуміння психології Аліси. Так, частотними є: Hatter (6), Absolem (4), Bayard (4), Hamish (3), Mallymkun (2), Lowell (2), Aunt Imogene (2). Tyт слід зазначити, що під час вирішальної битви із Жербельковтом Аліса звертається до себе самої. Цей випадок свідчить про рішення покладатися тільки на себе, розуміння того, що свої власні битви Алісі потрібно вигравати самотужки: ALICE: Six impossible things. Count them, Alice [10, 1:26:46].

2) Декларативи у формі окличних речень для емфатизації сенсу, а також під час висловлювання таких сильних емоцій, як подив, гнів, роздратування, розпач. Тут слід підкреслити, що емоції в персонажа виникають переважно тільки тоді, коли на її шляху до мети з'являються перешкоди: ALICE: What way? All I want to do is wake up from this dream! [10, 0:30:00].

Додамо, що для персонажа не є характерним прояв таких емоцій, як радість, захоплення, приємне здивування, розчулення. Наведемо чи не єдиний випадок висловлювання Алісою радості від неймовірного порятунку Капелюшника: ALICE: I'm so happy to see you! I thought they were going to... [10, 1:16:30].

3) Прямі квеситиви, які вимагають відповіді від співрозмовника, необхідні для просування сюжетних ліній; при цьому центром подій i/або рушійною силою виступає Аліса: ALICE: Where did they take him? [10, 0:43:17]. 
4) Прямі (ALICE: Take me to Salazen Grum, Bayard. And don't forget the Hat [10, 0:44:04]) та непрямі директиви (ALICE: We're going to rescue him $[10,0: 43: 21])$ як засіб реалізації лідерської функції персонажа.

5) Складні речення 3 причинно-наслідковим зв'язком для демонстрації логіки мислення, яка в тому викривленому світі, який описує автор, скоріше грунтується на інтуїції, ніж на загальноприйнятій логіці реального світу: ALICE: How can I be the "wrong Alice" when it's my dream? And who are you, if I may ask [10, 0:19:24].

Або інший приклад цієї ж групи: MAD HATTER: Have you any idea why a raven is like a writing desk? I'm frightened. I don't like it in here, terribly crowded. Have I gone mad? ALICE: I'm afraid so. You're entirely bonkers. But I'll tell you a secret... all the best people are [10, 0:56:14].

У мовленні Аліси майже відсутні оцінні лексеми як із негативним, так і $з$ позитивним значенням, відповідно, характерною є стриманість у висловлюваннях і оцінках; майже однакова частотність займенників першої особи однини та другої особи однини й множини демонструє, 3 одного боку, самодостатність, незалежність персонажа, вміння покладатися передусім на себе, а з іншого - піклування про інших, альтруїзм та концентрацію на потребах співрозмовника.

Висновки та перспективи подальших розробок. Психолінгвістичний образ Аліси Кінгслі у досліджуваному фільмі Т. Бертона складається так: 1) Аліса - феміністка, яка відстоює своє право на рівність 3 чоловіками (реалізується через тактику конфронтації, використання займенників першої особи однини); 2) вона прийде на допомогу іншим, незважаючи на смертельну небезпеку (актуалізація семи rescue, використання займенників другої особи однини та множини); 3) вона любить подорожувати, досліджувати нові землі, не боїться провести ніч на самоті просто неба (актуалізація семи curious); 4) найбільший iii страх - не бути здатною подбати про себе (актуалізація семи burden); 5) вона завжди прийме виклик від чоловіка і не відступиться, поки не переможе (реалізується через тактику конфронтації, актуалізацію оказіональної семи muchness); 6) вона цінує жіночу дружбу, але має більше друзів серед чоловіків (реалізується через показники екранного часу, кількість реплік у діалогах, апелятиви та прямі квеситиви); 7) вона керується інтуїцією частіше, ніж логікою (реалізується через складні речення 3 причинно-наслідковим зв'язком); 8) вона настільки сконцентрована на досягненні мети, що може сприйматися як байдужа і відчужена (реалізується через відсутність оцінних лексем, використання декларативів у формі окличних речень для емфатизації сенсу, під час висловлювання негативних емоцій, коли на її шляху до мети 3'являються перешкоди, для привернення уваги адресата чи для формування прямих i непрямих директивів).

Серед перспектив роботи - створення цілісної системи психолінгвістичних образів персонажів залежно від їх архетипу на матеріалі найбільш касових англомовних фільмів XXI століття.

\section{ЛIТЕРАТУРА}

1. Зубавіна I. Кіноархетипіка як ядро екранного наративу. Науковий вісник Київського національного університету театру, кіно і телебачення імені I. К. Карпенка-Карого. 2015. Вип. 16. С. 75-83.

2. Мельничук М.М. Теоретичне дослідження кінематографічних образів у рамках аналітичної психології К.Г. Юнга. Психологія і особиcmicmb. 2017. № 2 (12). С. 223-231.

3. Rowe J.P., Ha E.Y., Lester J.C. ArchetypeDriven Character Dialogue Generation for Interactive Narrative. In: Prendinger H., Lester J., Ishizuka M. (eds) Intelligent Virtual Agents. IVA 2008. Lecture Notes in Computer Science, vol 5208. Springer, Berlin, Heidelberg. 2008. Pp. 45-58. URL: https://doi.org/10.1007/978-3540-85483-8_5.

4. Adamson S. From empathetic deixis to empathetic narrative: stylization and (de)subjectivisation as processes of language change. Subjectivity and Subjectivisation: Linguistic Perspectives. Cambridge University Press, 1995. Pp. 195-224.

5. Леонтьев А.А. Язык, речь, речевая деятельность. Москва : Просвещение, 1969. 214 с.

6. Краткий словарь когнитивных терминов / под общ. ред. Е.С. Кубряковой. Москва : МГУ, 1996. $245 \mathrm{c}$.

7. Marilyn A. Walker, Ricky Grant, Grace Lin, Jennifer Sawyer, Noah Wardrip-Fruin and Michael Buell. Murder in the Arboretum: Comparing Character Models to Personality Models. In 4th International Workshop on Intelligent Narrative Technologies. Long Oral Presentation. 2011. URL: https://users.soe.ucsc.edu/ maw/ papers/int4-v10.pdf.

8. Schmidt V. The 45 Master characters. Cincinnati, Ohayo: Writers Digest Books, 2007. 338 p.

9. Grace I. Lin and Marilyn A. Walker. All the World's a Stage: Learning Character Models from Film. In Proceedings of the Conference on Artificial Intelligence and Digital Entertainment. AAAI Press. 2011. URL: https://users.soe.ucsc.edu/ $\sim$ maw/papers/lin-walker.pdf.

10. Alice in Wonderland (2010). URL: https:// toloka.to/t100446. 


\section{REFERENCES}

1. Zubavina, I. (2015) Kinoarkhetypika yak yadro ekrannoho naratyvu [Film archetype as the core of the screen narrative]. Scientific Bulletin of I. K. Karpenko-Kary Kyiv National University of Theater, Film and Television, vol. 16, pp. 75-83.

2. Melnychuk M. M. (2017) Teoretychne doslidzhennia kinematohrafichnykh obraziv u ramkakh analitychnoi psykholohii C. G. Jung [Theoretical study of cinematic images in the framework of analytical psychology of C. G. Jung]. Psykholohiia i osobystist, vol 2 (12). Pp. 223-231.

3. Rowe J.P., Ha E.Y., Lester J.C. (2008) ArchetypeDriven Character Dialogue Generation for Interactive Narrative. In: Prendinger $H$., Lester J., Ishizuka M. (eds) Intelligent Virtual Agents. IVA 2008. Lecture Notes in Computer Science, vol 5208. Springer, Berlin, Heidelberg. P. 45-58. URL: https://doi.org/10.1007/978-3540-85483-8 5 .

4. Adamson S. (1995) From empathetic deixis to empathetic narrative: stylization and (de) subjectivisation as processes of language change. Subjectivity and Subjectivisation: Linguistic Perspectives. Cambridge University Press. P. 195-224.
5. Leontev A.A. (1969) Yazyk, rech, rechevaya deyatelnost [Language, speech, speaking activity]. Moscow : Prosveshchenye. 214 p.

6. Kratkyi slovar kohnytyvnykh termynov [A concise dictionary of cognitive terms] ed. E.S. Kubriakova. Moscow : MSU, 1996. 245 p.

7. Marilyn A. Walker, Ricky Grant, Grace Lin, Jennifer Sawyer, Noah Wardrip-Fruin and Michael Buell (2011). Murder in the Arboretum: Comparing Character Models to Personality Models. In 4th International Workshop on Intelligent Narrative Technologies. Long Oral Presentation. URL: https://users.soe.ucsc.edu/ maw/papers/int4-v10.pdf.

8. Schmidt V. (2007) The 45 Master characters. Cincinnati, Ohayo: Writers Digest Books. 338 p.

9. Grace I. Lin and Marilyn A.Walker. (2011). All the World's a Stage: Learning Character Models from Film. In Proceedings of the Conference on Artificial Intelligence and Digital Entertainment. AAAI Press. URL: https://users.soe.ucsc.edu/ maw/papers/lin-walker.pdf.

10. Alice in Wonderland (2010). URL: https:// toloka.to/t100446. 